
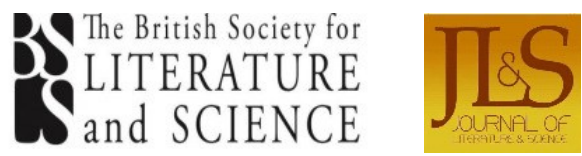

British Society for Literature and Science and Journal of Literature and Science

Prize Winning Essay 2014

\title{
(Re)Constructing the Knights of Science: Parasitologists and their Literary Imaginations
}

\section{Emilie Taylor-Brown}

When parasitologist Joseph Dutton died of African Relapsing Fever ${ }^{1}$ on 27 th February 1905, his obituary in the British Medical Journal read:

He was a true Knight of Science... the Galahad of that Group of enthusiastic young men who, with so little recompense for themselves, have pushed forward the cause of tropical medical science at such a rapid rate. (Ross 1020-21)

The accolade "Knight of Science" reflects tellingly on the author, fellow parasitologist Ronald Ross, ${ }^{2}$ and gestures more broadly to the romanticised construction of scientific expeditions. The implication here is that Dutton, who helped elucidate the aetiology of relapsing fever and discovered one of the causative agents of African Sleeping Sickness (Trypanosoma Gambiense), fought on behalf of science, risking his own life to propagate and advance tropical medicine as a discipline. The further appellation "Galahad" posits Dutton as Sir Galahad and scientific discovery as the holy grail of Arthurian legend. Colonial administrator Sir William MacGregor similarly lionises the profession in an address given at the London School of Hygiene and Tropical Medicine in 1900, "you will in all probability be able to establish the existence of maladies at present unknown and unrecognised [. . . can any man desire greater glory?" he asks (978). The "glory" associated with scientific research, particularly research in the colonies, is a concept propagated by its association with the broadening of frontiers (both figurative and literal), but, for parasitologist Ronald Ross, an unfulfilled ideal that he struggles with his entire career. How far is this "glory" a true reflection on scientific pursuits or a constructed cultural image?

In his Memoirs (1923) Ross recalls that "a witty friend of [his] once remarked that the world thinks of the man of science as one who pulls out his watch and exclaims: 'Ha! half an hour to spare before dinner: I will just step down to my laboratory and make a discovery!"' (v-vi). This unrealistic image of success is precisely the reason he proposes for writing his Memoirs, which, the subtitle boasts, include a "full account of the great malaria problem and its solution." However, regarding the public's delusions surrounding the "man of science" he goes on to say, "who, but men of science themselves are to blame for such a misconception" (vi). He criticises the history of discovery as a "record of results" that eschew "that sacred passion for discovery that leads to them" (vi). However it is just this "sacred passion" 
that is constructed in the many discourses related to parasitology and tropical medicine at the turn of the century. In Membranes Laura Otis examines the interdisciplinary discourses surrounding the changing concept of selfhood in the nineteenth century, noting a confluence between "political and biological thinking" (4). Following the development of microbiology, scientists, she argues, "assumed the heroic role of soldiers, the creators and defenders of empire" (28). The adoption of this heroic persona by parasitologists in the use of Arthurian archetypes and metaphors, as well as those of Ancient Greek and Roman mythology, served to romanticise parasitology by grounding it in literary history. The anxieties surrounding selfhood that Otis examines are pertinent to parasitological research, which necessitates discussions of self and other as host and parasite. The status of parasitologists as "creators and defenders of empire" is particularly fitting given their direct and indirect involvement in imperial expansion. The parasite as both "other" and somatic invader threatens the integrity of British selfhood. Stephen Arata recognises the fear that the "civilised" world might be colonised by "primitive" forces, which he identifies in late-nineteenth century popular fiction, as symptomatic of a widespread anxiety concerning the moral, social and imperial decline of Britain as a global power (622). This notion of reverse-colonisation, of "imperial practices mirrored back in monstrous forms" (Arata 623) articulates a fear that the Western world will fall victim to the dangers of the colonial environment - that Western sanitary science will prove ineffective against tropical disease. The dual fears of national and personal usurpation implicate ideas about national identity in the construction of "self"; parasitologists, who sought to alleviate the infiltration of British (and colonial) bodies, and in doing so strengthen Britain's position as a global power, recognised the significance of this relationship. The infusion of parasitology discourse with British myths about nationhood enabled parasitologists to create public selves that garnered cultural authority.

The examples outlined at the beginning of this essay gesture toward a stock of metaphors and images that were appropriated by parasitologists and civil servants alike, to delineate the place of parasitologists within the wider political framework of nineteenth century England and her colonies. Consequently, the imagery surrounding Parasitology performed multiple functions, including the legitimizing of western medical authority, the characterization of tropical medicine as a prerogative of the nation, and the encouraging of medical students to specialise in this form of training. The parasitologist was a new and hybrid figure at the turn of the century replete with conflicting ideologies and multifarious cultural meanings. To consider this further this article analyzes the part that parasitologists themselves had to play in this construction, exploring their scientific and literary output in conjunction with the cultural history in which they were situated.

When parasitologists were gaining their professional status at the turn of the century, two significant movements had risen to prominence in popular culture. The first of these, reflected in the proliferation of colonial adventure stories, and the infiltration of empire as a plot device in British horror, Detective, Spy, and Romance fiction, was the shifting power play of England's imperialist agenda. The prominence of tropical diseases and their function as barriers to Britain's expansionism led to the forging of associations between the colonies and Parasitology as an emergent discipline. The gathering of knowledge concerning tropical disease etiologies, their interactions with colonial life and landscape, and their medicinal treatment, directly benefitted the workings of empire. Concerns over the health of the British Empire both in terms of day-to-day living and the impact of parasitic disease on commercial 
trade - led to the instigation of the London and Liverpool schools of Tropical Medicine in 1898 and 1899 (the first institutions in the world to specialise in research and training in Tropical Medicine and Parasitology). ${ }^{3}$ Consequently the rhetoric of empire became indelibly associated with parasitologists and their research, linking the progress of the discipline with the progress of the Empire at large. Leading parasitologist and mentor to Ross, Patrick Manson asserted in 1897 that the systematic teaching of tropical medicine would soon be universal in Britain "because our country is at the centre of a great and growing tropical empire" (986). The implication that the success of the Empire necessitated knowledge of tropical medicine is clear; indeed the British Medical Journal asserted in 1898 that "the enemy of civilisation and colonisation in Africa is not so much Mahdism as malaria" ("Medicine in the Tropics" 909). The importance of parasitologists as facilitators of empire was constructed in relation to their ability to improve the health, and by extention mental acuity, of its inhabitants:

In this colossal task of grappling with its mighty destiny, the British Empire will require the best efforts of her myriad sons and daughters. Since a very considerable portion of the Imperial territory is either tropical or subtropical, and since the inhabitants of those lands will be required to contribute their quota of deliberation and judgement to the solution of the great problem of the race, it follows that he who achieves a triumph in tropical bacteriology is laying one of the stones upon which will rest the everlasting bastions of a strong and vigorous Empire. ("Empire Leading Article" 1)

Furthermore, the work of parasitologists became synonymous with the building of Empire, as McGregor notes in drawing an analogy between parasitologists and construction workers: "It appears to me to be more or less like this: Manson was the surveyor, Laveran made the road, Ross built the bridges and laid the rails, and Grassi, Bastianelli, Bignami, and Celli provided the rolling stock" (980).

The second movement to register its prominence was the, by this time well established, medieval revival, following the publication of Tennyson's Idylls of the King between 1859 and 1885 (which sold 10,000 copies within the first week) and the first modernization of Malory's compilation of Arthur's tales, which had 6 further editions and 5 competitors before the century ended. Many parasitologists consciously negotiated these two movements, appropriating and hybridizing Imperialist and Arthurian rhetoric in order to construct their professional identities. These appropriations serve to imbue research discoveries with a level of cultural investment and legendary significance, a sentiment that finds congruence with George Eliot's observation that "A remnant of the mythical lurks in the very sanctuary of science" (qtd. in Beer 4). The notion that the mythical is always "lurking" within science suggests that it does not belong there, or is not wanted - left over from the bygone days of pre-science. However, this remnant of the mythical is not just lurking, but fully integrated into the rhetoric of turn-of-the-century tropical medicine. The need to legitimise a newly emerging field of study, in addition to the desire to gain government support and funding, meant emphasis was placed on the need for the profession to engage with wider national interests and to effectively communicate its relevance to medicine - in short parasitologists increasingly needed to sell themselves.

In William McGregor's address at the London School of Hygiene and Tropical 
Medicine in 1900 he noted the importance of malarial research, which had already brought to light "some of the finest examples of human intelligence, perseverance, and observation, and unveiled some of the most wonderful workings of Nature" (980). He continued:

To myself this chain of marvels, full of poetry and religion, nowhere better seen than in the splendid illustrations of Drs. Ross and Fielding-Ould, always recall the words of the second-greatest Teuton of the century:

How it all lives and moves and weaves

Into a whole! Each part gives and receives,

And each to each their golden vessels lend,

Fragrant with blessing, as on wings,

From heaven through the earth and through all things,

Their movement thrusts, and in all harmony it sings! (980)

By likening the "chain of marvels" to Goethe's Faust, McGregor associates scientific research with religion and the pursuit of divine knowledge. The lines he quoted concern the unity and transcendence of Nature, as represented by the macrocosm, "How it all lives and moves and weaves/Into a whole!" and reinforce the idea that this unity is inherent in scientific observation. What Faust perceives in the philosophical idea of interconnected Nature, McGregor perceives in the diagrams of Plasmodium lifecycles. He goes on to compare the elucidation of the life cycle of the microscopic malaria parasite Plasmodium spp; with the location of the cycle of the "Demon star" Algol; ${ }^{4}$ the pinpointing of the position of Neptune; ${ }^{5}$ and the discovery of gold in Australia. This sets up a series of points of reference with increasing amplification: cellular, global, planetary and galactic. There is a reinforcement of the unity of Nature in the mirroring of systems at different levels of existence; the microscopic, to his mind, is just as complex and elegant as the orbits of the universe. This microcosmic rhetoric complements the conflation of body and landscape, common to medical cartography and imperial romance, and was increasingly used by parasitologists to visualise and communicate the movements of parasites within the body. Helminthologist $\mathrm{T}$ Spencer Cobbold uses the metaphor to describe the lifecycle of parasitic worms:

[Entozoa are] a peculiar fauna, destined to occupy an equally peculiar territory. That territory is the widespread domain of the interior bodies of man and animals. Each animal or "host" may be regarded as a continent, and each part or viscus of his body may be noted as a district. (4)

Parasitologists Ronald Ross and Patrick Manson used the same conflation of body and landscape when talking about their research as a metaphorical journey. In correspondence with Manson, Ross insists he will "follow the flagella" and "pursue the plasmodium," paralleling symbolically both the parasite's migration through its hosts, the letters themselves on their travels from Ross in India to Manson in England, and the quests of King Arthur's knights. Using the trope of the hero's journey, he compares research to expedition by setting up parallels between the movement of parasites between and within hosts, and the conquest of foreign lands. Manson compounds this use of the quest motif in a letter dated $21^{\text {st }}$ June 1895 :

I look forward to receiving [your letters] with the greatest interest and when 
a mail passed without getting one the other day I was terribly disappointed for I thought you had fallen sick, or that you had got a check, or that you had given up the quest. Above everything, don't give it up. Look on it as a Holy Grail and yourself as Sir Galahad and never give up the search. (31).

The quest motif is one that characterised the parasitology narrative; Ross would use the Galahad reference when eulogizing Joseph Dutton in 1905. Manson's use of this rhetoric in private correspondence, and McGregor's glorification of the profession to medical students, suggests both a desire to sell the narrative to parasitologists (in addition to the general public) and an internalization of that narrative by its proponents.

The success of this narrative relied on the cultural association between Arthurian legend and British expansionism, and significantly, the idea of an historically revered homeland from which to govern. Stephanie Barczewski suggests that supporters of British Imperialism used the King Arthur legend to demonstrate that "Britons have for centuries looked outwards towards their burgeoning empire and territorial expansion," associating a celebrated and venerated history with a promising Imperial future (201). In a bid to demonstrate this effect, she identifies the prominence of the sea (fundamental to colonial travel and trade) with nineteenth-century reinterpretations of Arthurian romances. The popularity of this motif in Arthurian adaptation connects mythic movements with Imperial endeavor. Furthermore, she suggests a correlation between the increasing market for tourism in Cornwall (Arthur's homeland) with this valorization of the ocean.

The alleged site of King Arthur's birth at Tintagel and his death at Camelford both belong to Cornwall, a place where the sea is a constant intruder. In 1851 Arthur's castle at Tintagel was turned into a tourist site by Rev. R. B. Kinsman, who renovated the path to the headland where the castle stood. Kinsman's renovations meant that it was made truly accessible to the general public for the first time. This coincided with an increase in railway infrastructure in the south west, stimulating the development of a vigorous tourist industry involving a previously isolated part of England, which came to be known as "the land of King Arthur" (Barczewski 204). This new tourist destination helped to compound the association between Arthurian legend and the sea, influencing nineteenth century reinterpretations, and their connections to current pursuits of Empire. Parasitologists appropriated and strengthened this connection. Embarking on ocean expeditions to explore unknown lands, and fighting to protect the Empire with science, parasitologists inhabited an allied heroic position. Owing to the allegorical construction of parasitological research, they retained the overtones of imperial romance, even when not taking part in scientific expeditions. By analyzing the bodies of patients, already established to parallel allegorically the colonial landscape, scientists - like explorers - might find "treasures that for ages have been missed," wrote one reviewer in the British Medical Journal in 1910 ("Annals of Tropical Medicine" 880).

Press publications upheld the parasitology identity by situating the field within a mythic narrative: "Old legends and fairy-tales tell us of battles with giants and dragons; modern medical science tells us of battles with microbes too small to be seen," wrote one author for The West Australian in an article about the "deadly" mosquito (M.W.G. 5). Furthermore, the Arthurian framing was kept alive through conscious press characterization, such as in this tribute to Ronald Ross, written by fellow parasitologist William MacCallum: 
Sir Gawain asked the knight if he knew any adventures in that country. "I shall show you some to-morn" said the old knight, "and these marvelous." So on the morn they rode into the forest of adventures." The forest of adventures for Sir Ronald Ross - then plain Major Ross of the Indian Medical Service - was the teeming insect life of India. At Secunderabad, on August $20^{\text {th }} 1897$, he made an epoch-making step into the unknown. (5)

The narration of a valiant knight hungry for adventure had ramifications, not just for the furthering of empire, but for the bravery with which this furthering was portrayed. A correspondent for The Daily News Weekly compounded this construction of bravery: "of a bright and jaunty disposition Major Ross regards a visit to the swamps of West Africa as he would a trip to Paris" ("A Malaria Expedition"). The parasitologist was the valiant knight, the brave explorer, the conquering general, the mythic hero all rolled into one, and bore cultural significance as the facilitator of progress. As Ross insisted in an article published anonymously in the British Medical Journal in 1906: "He [the discoverer in science] serves not only one people but the whole world, and not only one generation but all time. Without him the inventor would not succeed, and the general, very often, not conquer" ("A British Nobel Prize"). The success of Empire was tied so thoroughly to the work of parasitologists that an article concerning "the prosperous and progressive future of the British Empire" even referred to malaria with the adjective "anti-imperial" ("Empire Leading Article"). Ross, by extension, was posited as distinctly pro-imperial; working to conquer Malaria, he was billed as a literal empire-builder:

Mr. Ure, when Lord Advocate, was fond of saying up and down the country that nobody could add an acre to the land originally given to us by the Creator. As a saleable and inhabitable commodity, I wonder how many acres Sir Ronald's discoveries have added to the map of the empire? [. . .] engaged in his gigantic fight with the pigmy jungle foes of man. (Faulds, "The Reward of Research")

This characterization of Ross's adversaries situated malaria firmly in tropical territories, despite its prevalence in Italy, Greece and elsewhere in Europe. The appellation "pigmy" referred to both a race of people of short stature in Central Africa and South East Asia, and to diminutively small objects and animals. This double meaning, and addition of "jungle," posited Ross's fight as against the colonial landscape, reinforcing the sanitizing rhetoric of British Imperialism.

At the Nobel prize reception for Ross in 1902, he was described as "a hero from Africa who had been occupied in a war, not against his fellow men, but against a most insidious enemy to mankind" ("Liverpool" 48). The branding of Ross as a "hero" against an "insidious enemy" - that of Malaria - cast Ross as a savior; Alfred Lewis Jones then compounded this image by highlighting Britain's debt to "all those brave men who had gone into such countries with the object of improving the conditions of life for their fellow-men" (48). He insisted:

Such work is not of a selfish character; it was not merely a national movement, it benefited the whole world; and men such as Professor Ross made the countries better, not only for those who belonged to them, but 
better for people of other nations who went to them, and in this way the whole world was benefited (48).

In this high praise we might see another attempt to glorify the profession by connecting the expansion of the British Empire with the improvement of the globe at large. The emphasis on the impact of individual researchers created a story with memorable protagonists who formed the public face of the discipline. These protagonists were in turn part of multiple narratives, be they narratives of colonial medicine, public health or professional development. The construction of the "oneman" narrative was often accompanied in the lay-press by hyperbolic descriptions of adversity, which exaggerated the immediacy of the danger:

His [Ross's] research took him into the deadliest districts of West Africa, where for months he risked his life, every hour, night and day, for the cause of medical science and humanity. ("Martyrs to Science")

The bravery of the individual was similarly hyperbolised:

Dr. Sambon, Director of the new [Parasitological] department was one of several scientific heroes who deliberately lived in a hut over an ancient tomb (from which a skeleton was taken) in the swampiest part of Rome. ("Perilous Pets")

As was the inadequacy of the resources, contributing to the glorification of the individual researcher's personal strength:

"The best of professor Ross's work had been done in a hut with a microscope, two needles and a matchbox. ("Correspondence")

The glorification of the individual allowed - even encouraged - the divulgence of personal details otherwise denied to the reader of scientific research. This facilitated a familiarity with the figure that cultivated a potential for celebrity. Offering commentary on the character of the individual, publications often translocated the researcher's scientific accomplishment onto their endeavours at large, or else looked for the preconditions of success in their physical and mental constitutions. The Children's Newspaper for example, under the title: "Men you will hear of when you grow up," described Ross as "a man of genius whose heart is charged with music and sunshine, as his brain is charged with colossal ideas" (919). The newspaper purported that Ross had single-handedly solved the malaria problem, "while the rest of the world were sleeping," reinforcing the idea that one individual could change the world. Increasingly the Parasitology narrative blurred into myth, and ever more diverse groups participated in the construction of that myth.

Ross received correspondence from doctors seeking advice, researchers in allied disciplines congratulating him, would-be patients wanting diagnoses, and even fans wanting autographs. One correspondent sent him a poem she had written which alluded to the impressive sight of Ross and colleague Lt. Col. Stephens crossing the Liverpool University quadrangle. As they cross the quad to reach the ThompsonYates laboratories, they are watched enviously by "haughty arts men" "with noses pressed against the glass," and engineers shamed by such an "inspiring sight": 
Here come - now, glory be to God!

The colonels twain across the quad

And one is dreamy, pale and long

And one alert, and brown, and strong. (Allman, 1-4.)

Just as fellow parasitologists Kinghorn and Montgomery were described by one newspaper as "fine specimens of British manhood" ("Insect Borne Disease"), Stephens and Ross took on the physical attributes of heroic figures.

In an article concerning the etiology of Kala-Azar ${ }^{6}$ Surgeon-Major Giles used a reference to Alexander the Great to lampoon a colleague's suggestion that the disease was caused by malarial infection complicated by the presence of ankylostomes:

An ordinary man would indeed see at once that such a position is untenable, but Dr. Rogers, like a medical Alexander, cuts his Gordian knot by announcing that Assamese malaria is infectious. In this he places himself at variance with not only the scientific, but the popular opinion of the entire world. (1)

Here Giles characterises Rogers's solution to the problem of Kala-Azar as analogous to Alexander the Great's severing of the Gordian knot. This analogy is a poignant one, which requires some unpicking. The theory advanced by Rogers was flawed, owing to its predication on malarial poisoning, which was not infectious, unlike Kala-Azar. However Rogers posits a solution: Assamese malaria is a special variety of the disease, which is infectious. Giles points out the short-sightedness of this position; while it indeed reaches a solution, it is not backed up by evidence and thus is like cutting the knot, rather than untying it. The use of the Gordian myth reinforces the notion that parasitologists understood their profession through mythic narratives. However the departure from Arthurian rhetoric perhaps suggests an imaginative hierarchy. Alexander the Great, leader of the Macedonian Empire, was indeed a figure of imperial might, comparable to the leaders of the Roman, Byzantine and Mughal ${ }^{7}$ empires. Reference to such figures invoked past histories as models for the British pursuit of Empire. Significantly, the decline of these great empires was attributed to tropical disease:

The extraordinary collapse in politics, art, literature and morals, and all that constituted 'the glory that was Greece' is now believed to have been caused by malaria, which was very probably also the main reason why 'the grandeur that was Rome' gradually became dimmed, and the once-potent Roman Empire sank to a level of a tenth-rate power. The sword of the Roman legionary was as sharp as ever, but it could not parry the thrusts of the mosquito's rapier. (MacCallum, 5)

Where these empires failed Britain would not because the nineteenth-century model is endowed with a secret weapon - Tropical Medicine. Unlike the great empires that came before, Britain's focus was on successful colonising (rather than simply conquering) and thus on effective and lasting solutions to the problems of parasitic disease. For Giles, this success was analogous to unravelling (rather than cutting) the Gordian knot. 
The efficacy of such mythologisation was commented upon by Ross in Science Progress in 1916:

The only manner in which science can be taught to men is by way of narratives of events which, though they may not actually have occurred as described, are occurring over and over again in history and in our lives just as Euclid's book was the first to crystallise geometry in sets of definite propositions with figures which are never actually found in nature. ("Homer, Dante, Shakespeare, and Cervantes")

Arguing for the necessity of these kinds of semi-fictitious narratives, he noted: "the constructions of the men of science [. . .] have to be idealised, partly for brevity and partly for fixing the attention of the public," a sentiment which appeared to justify the widespread adoption of myth in the reporting of Parasitology research. He elaborated on this relationship by suggesting that science relied on art for its "presentment." He argued that "the great histories and biographies, as well as other epics and novels, belong to the same class of work" as those of science - that is - work that aimed to educate the public. The blurring of these different kinds of writing, or indeed the use of art to facilitate a transfer of knowledge can be seen in the memorandum of Walter Myers published in The Financial News in 1913. Myers, a parasitologist, who died of Yellow Fever while working for the Liverpool School of Tropical Medicine was remembered with a brief memorandum of his life and work, which ended with the line: "The Rest is Silence." Not content with the reference to Hamlet, The Financial News, republishing the memorandum, saw fit to add the

following lines from Tennyson's In Memorium (LXXV. 20-24):

So here shall silence guard his fame;

But Somewhere, out of human view,

Whate'er thy hands are set to do,

Is wrought with tumult of acclaim. (qtd. in "How to Assist Tropical Medical Work")

These literary additions compounded the integral function of art as helping to frame scientific figures and their achievements.

Owing in part to widespread classical education in the nineteenth century, and in part to the preeminence of Classical Greece as providing the foundations for western civilization, ${ }^{8}$ ancient Greek mythology formed another reservoir for medical analogy. The mythic Greek hero provided a connection to past civilizations and empires, myth being for the Ancient Greeks "the major formative power of cultural progress" (Burkert xii). Indeed Frank Turner argues that for the Victorians, Greek civilization represented not "the Ancients," but "distant contemporaries who had confronted and often mastered the difficulties presenting themselves anew to the nineteenth century" (xii). To this end, their myths were repurposed for scientific analogy, the mythic hero often fused with the Knight Errant - a figure associated with Britain's Arthurian myths of nationhood - to better represent the tribulations of the British Empire. In 1898 Dr Sambon used a figure from Greco-Roman mythology to symbolise what, to his mind, was the greatest obstacle to African colonization.

But there remains the great tropical belt, with its vast and rich territories extending over more than a third of the surface of the globe. This, surely, 
must be the Promised Land; but we dare not enter, because at its gates stands a terrible monster - the Cerberus of prejudice. (589)

Sambon used this analogy to dispel erroneous notions that Africa could not be colonised by "the white man" owing to geographical or ecological incompatibility. He was referring specifically to the popularly held connection between tropical climate and disease: "It is the almost universal opinion that the European cannot colonise the tropics, but must inevitably fall, sooner or later, a victim to the influence of their deadly climate" (Sambon 589). However, he went on to point out the folly of this connection, ${ }^{9}$ highlighting the importance of new medical knowledge:

One time, undoubtedly, these diseases were attributed to the direct and sole agency of solar heat, just as malarial fevers were attributed to the moonshine; but now they have been inscribed deeply on the tablets of bacteriology, and certainly the demonstration that disease belongs to the domain of parasitism is the greatest advance that medical science has ever made. (590)

Sambon's use of Cerberus to dispel this notion is intriguing because it is problematic. Cerberus is a familiar character from Greek mythology, the fearsome three-headed, serpent-tailed hound that plays gatekeeper to the Underworld. Certainly, this is an effective metaphor for the obstructions of prejudice. Sambon's use of Cerberus, however, posits the tropics as the Underworld and the journey across the Atlantic as tantamount to crossing the river Styx (a formidable stretch which separates the Earth from the Underworld). Indeed, the absence of light in the Underworld might find congruence with the naming of the "dark continent." That said, Sambon does refer to the tropical belt as "the promised land" perhaps to draw an analogy to the belief, expressed in the Aeneid, that Elysium was located in a special region of the Underworld (Hard 117). Thus Elysium symbolises the potential wealth and resources in the tropics, which can only be found by persevering through the barrenness of the African continent, in turn symbolised by the Underworld. However, before the British can find Elysium (or happiness in Africa) they must first lull to sleep the Cerberus of Prejudice $^{10}$ - that is dispel the notion that the tropics are uninhabitable. Significantly, Patrick Manson uses the same analogy in 1907, although his Cerberus was not prejudice, but disease: "The Cerberus that guards the African Continent, its secrets, its mystery and its treasure is disease... (which I would liken to an insect)" (qtd. in Watts 213). This final clause suggests that Manson refers specifically to parasitic diseases, many of which have insect vectors.

Manson's and Sambon's gatekeepers are effectively one and the same; the prejudiced notion that Africa is uninhabitable to the white man stems from an association between the climate and disease. Both regard the taming of disease as the key to colonization. Uniquely, Sambon advocated a disassociation between heat and disease, which he deemed not to be causatively linked. As the British Medical Journal reported in 1897: "Like everyone else, Sambon recognises two [obstacles to tropical acclimatization] - heat and disease. But he differs from almost everyone else in accentuating the fact that these two are [. . .] independent of each other; in fact entirely distinct" ("Europeans in the Tropics" 93). This dissociation dispelled the notion that the tropics were noxious and deadly environments in and of themselves, and suggested that a third factor (the parasite) is what caused disease, and thus might be overcome by Europeans. Man could not change the tropical climate, but he might 
be able to avoid parasitic infection, and thereby achieve acclimatization. In this way, parasitologists were again indirectly valorised by their insistence that the only thing standing in the way of European acclimatization was parasitic disease, and by extension the only ones able to grant acclimatization were parasitologists.

The transformative powers of parasitology and its allied practices of public health and sanitation are an integral part of the parasitology narrative - a highly political mythology constructed by and about its proponents. This construction can be seen in the correspondence between Ronald Ross and Lord Lever - benefactor of the Liverpool School of Tropical Medicine. Lever wrote to Ross in 1911 to inform him that he had received a drama in one act, anonymously signed, which had St Peter send "a soap-maker," billed as the chair of the --- School of --- Medicine --- ${ }^{11}$ and "a scientist," who "made a great discovery," to Hell (Lever, Letter to Ronald Ross. 27 Dec. 1911). He enclosed the play and composed a second act, which he provided under the authorship of "a certain soap-maker" who "often gives rise to reflections" ("The Gates of Paradise"). The scientist is Ross, and the soapmaker, Lord Lever, ${ }^{12}$ and given the subtitles: "By a scientist" and "By a soapmaker" respectively, it seems likely that the first act was composed by Ross, and the second by Lever. The gathering of applicants who are "mostly from Liverpool, Ship owners, Professors, Business Men and so on" compounds this by situating the drama in dialogue with the Liverpool School of Tropical Medicine and its proponents. ${ }^{13}$ The first act takes place at the "Gates of Paradise" where St Peter is reviewing the applicants for admittance to heaven. After meeting a Parson and sending him to Hell for the insincerity of his prayers and his failure to convert anyone to Christianity, St Peter is met with a scientist:

\author{
St Peter: [. . . Next. Who are you? \\ Scientist: A poor man of science, Sir. \\ St Peter: Oh! I don't understand that lot. What has he done? \\ Secretary: He made a discovery once, Sir - many years ago. \\ St Peter: $\quad$ Ah yes, I've read about it in our Science Jottings. And what has \\ he discovered since then? \\ Secretary: Nothing, Sir. \\ St Peter: Monstrous! Why not? Why haven't you used your talent? \\ Scientist: Please, Sir, I have had to spend all my time writing letters, \\ attending committees, and dining with the next applicant; so \\ that I have had no leisure to think and work properly. \\ St Peter: Rot! Down you go. Fifth class [... .]. ("The Gates of Paradise")
}

These lines can be read as an allegory for the mistreatment of scientists and the lack of understanding on the part of general public, a reading which is supported by Ross's campaigns for better recognition and remuneration for scientific workers. The speed with which St Peter dismisses the scientist's discovery suggests both a belittling of the significance of his research, and a lack of understanding of the political nuances of such work. Scottish scientist, Henry Faulds, commenting on Ross's remuneration campaign, captured the sentiment behind this interaction when he asked:

Why should only well-paid warriors, diplomats and civil servants be additionally requited for often purely conventional services, while those who painfully penetrate with ultimate success into the unknown, but fertile 
regions receive nothing for their expenses, and often not even the barest form of thanks? ("The Reward for Research")

Alternatively the interaction might be read as a sincere criticism of the amount of time spent reaping the rewards of discovery at dinners and committees, by someone who, either seriously or teasingly, Lever accuses of "lay[ing] sacrilegious hand on the scientist" (Letter to Ronald Ross. 27 Dec. 1911). Either reading, however, suggests a disconnect between the perspectives of the workers of the Liverpool School of Tropical Medicine and their political reception at large. Faulds' notion of scientists as penetrating into the unknown and subsequently transforming the tropical landscape, is played out in the second act, which has the scientist, parson and soap-maker descend into the deepest regions of Hades. A conversation with "his Satanic majesty" reveals that the Underworld has been transformed owing to St Peter's dislike of Scientists, whom he sends to Hell, and who then proceed to improve it beyond recognition.

His Satanic Majesty: The fact is we get so many distinguished scientists that they are improving the place entirely out of my recollection. They introduce Town Planning Schemes, Garden Cities, Art Galleries, Museums; to say nothing of Tropical Wards, Scientific Medical Research and other advancements. ("The Gates of Hades")

The transformative powers of scientists are here made apparent. Parallels with the tropics are upheld by way of references to "climate," which has of course been improved by the scientists in Hades, and by reference to other markers of colonial space. ${ }^{14}$ The journey to Hades takes place by train, perhaps nodding to the railway infrastructure of the colonies, a seminal factor in the successful colonisation of central Africa. Satan facilitates further comparison when he says:

The very men who invented mosquito proof curtains have introduced here fire proof curtains [. . .] and there is one distinguished scientist connected with the Liverpool School of Tropical Medicine, whom we are expecting here shortly and whom we have good reason to believe has succeeded in inducing a very wealthy Baronet, living in the South of England somewhere near Ascot, to fit up a cold chamber on the Haslam Improved System. ("The Gates of Hades")

This likely refers to Ross's work studying the effects of cold on animals (and people) infected with trypanosomiasis (see: Letter to Sir Alfred Lewis Jones). A cold chamber, made by Sir Alfred Haslam, was erected at the University around this time, paid for by Sir Edwin Durning-Lawrence (see: Ross and Thomson 227).

The parallels with recognisable real-life developments, like the implementation of mosquito nets in the tropics and the construction of the cold chamber at Liverpool, situate the drama firmly in dialogue with the politics of the discipline. In their letter correspondence, Lever and Ross exchange veiled compliments, which - given the parallels discussed here - suggest they see British Imperialism or at least the work of the Liverpool school (of which Lever was a benefactor) as a sanitising and transformative force. Their dramatic counterparts bleed into real life, and their public personas are imbued with Underworld mythology: "You 
make me blush when you talk about the Ignominious soapmaker improving Hades. It is the new departure in Town Planning being carried out by men of science headed by R.... R..." (Lever, Letter to Ronald Ross. 30 Dec. 1911). The private nature of this mythologisation provides further strengthening for the internalisation of the narrative, suggested earlier by the correspondence between Manson and Ross. However the reality of research is gestured to by the interactions of the first act. The transformative power of parasitologists, exemplified here, is an idealisation; despite providing the keys for prophylaxis against parasitic disease in the tropics, parasitologists do not work in isolation and cannot guarantee the implementation of their findings. Research is hampered by financial restrictions and subject to administrative red tape. ${ }^{15}$ Ross's own research was interrupted by his relocations with the Indian medical service, and lack of government support (both Indian and British) (See: "Letter to Surgeon-Major Owen"; Ross, Memoirs). His campaigns for better remuneration, recognition, and pensions for scientific workers (which included widely-read articles in the laypress) resonated with the public and cultivated support: "I have been very struck with your letter in "The Times" [. . . ] I should be very pleased to add to such a fund ( $\$ 500$ anonymously)" (Yarrow, Letter to Ronald Ross); "I have just read your letter in today's "Times," I wish I could send a cheque worthy of such an object" (Glenny, Letter to Ronald Ross). However the campaign was also met with resistance:

The claims of "research" workers to have benefitted mankind are matched only by their insistent pleading for grants and complaints of inadequate payment [. . . I I fail to see what claim [they have] upon the public purse of this country. ("Sir Ronald Ross and his Petition" 126).

Such scepticism concerning the social value of parasitologists reinforced the need for their imaginative re-construction. The use of heroic discourses and underdog motifs in both private and public correspondence contributed to the dramatization of the discipline - a dramatization that served to glorify individuals and legitimise their fiscal demands. The Northern Star recognised this process, when it stated that "[Ross's] conquest of Malaria [was] one of the romances of scientific investigation," ("Sir Ronald Ross, Famous Scientist Ill" 3), while the Brisbane Courier actively participates in this romantic construction, noting:

His fight against the malaria-carrying mosquito has been truly described as more romantic than any story of knight against huge dragon [...] this kindly knight was to show himself possessed of patience, imagination, determined and highly-developed reasoning power, and above all faith and courage. ("Sir Ronald Ross" 10)

What started out as an imaginative narrative to frame their research became so invested in turn-of-the-century rhetoric pertaining to imperial epidemiology, that the mythic "knight of science" became an archetypal figure for representing the tropical scientific researcher. The multi-level impact of disease: biological, verbal, political, social and cultural, which Charles Rosenberg discusses in Framing Disease, (xiiixxiii) was carefully negotiated by parasitologists, who inflected their field in ways that would legitimise it in relation to public policy, as well as cultivate a new professional identity, using the myths the British told themselves about nationhood to their own advantage. 


\section{Notes}

1. Dutton caught African Relapsing Fever or 'Tick Fever' while carrying out autopsies on infested cadavers with friend and colleague John Todd, as part of the Liverpool School of Tropical Medical's Congo expedition to investigate the parasitic disease Trypanosomiasis or 'African Sleeping Sickness'. He caught Relapsing Fever toward the end of the expedition in 1904 and died almost a year later at just 29 years of age.

2. Sir Ronald Ross won the Nobel Prize for medicine in 1902 for his research proving that the anopheles mosquito is a vector for malaria. He was heavily involved in public health and sanitation campaigns for the colonies, and researched a number of other parasitic diseases include Kala-Azar (Visceral Leishmaniasis). He campaigned for pensions and remunerations for scientist workers, was a poet, mathematician, novelist and playwright, and the Liverpool School of Tropical Medicine's first lecturer.

3. Two founders of the Liverpool school - Alfred Lewis Jones and John Holt of Elder Dempster and John Holt shipping, both had established main lines between Liverpool and West Africa.

4. Algol, the so called 'Demon star' or 'blinking demon', probably gains its name from the fact that the variability in its brightness made it look like a giant blinking eye peering down at the Earth. In 1782 Goodricke advanced the eclipse theory to account for these fluctuations in brightness and in 1880 Pickering reaffirmed the theory. Vogel confirmed it unquestionably in 1889, identifying Algol as a binary pair undergoing mutual eclipses (Olcott 303; "Spectoscopic Binary Star").

5. Before the discovery of Pluto in 1930, Neptune was considered the furthest known planet and thus its discovery in 1846 was considered to push at the boundaries of the known universe. However, more importantly, the position of Neptune was mathematically predicted before it was observed, suggesting a logical pattern to life, which Benjamin Gould held as "utterly unparalleled in the whole history of science," a phenomenon imbued with "romance and poetry" (Gould 3-4).

6. A parasitic infection also known as Visceral Leishmaniasis. The cause, protozoan parasite Leishmania donovani, was isolated independently by Charles Donovan and William Leishman in 1903. Before this, the disease was thought to be a complication of malarial infection (even a quinine-resistant form of malaria) - a position which many thought untenable owing to the fact that K.A. was infectious, while malaria was not. (Both however were found to be transmitted by insect vectors - sandfly and mosquito respectively - and thus neither truly infectious.)

7. Patrick Brantlinger notes, when discussing Tennyson's 1892 poem “Akbar's Dream", that "Akbar is an Oriental King Arthur," and suggests that Tennyson uses this parallel to prophesise the triumph of the Empire: "The great work he [Akbar] has begun of civilizing the Indian wilderness will collapse, but the British will take it up again and complete it on a permanent basis" (10).

8. Turner argues that the classical world was at the heart of Victorian intellectual thought (xii).

9. He is in fact so against this climate connection that he insists "sunstroke" is not caused by exposure to the sun, but is an infectious disease!

10. The sibyl accompanying Aeneas on his journey through the Underworld puts Cerberus to sleep by tossing him a drugged honey cake, whilst Orpheus uses a harp to lull Cerberus into submission when he descends to the Underworld to rescue Eurydice (Webber and Feinsilber 107; Cox 20). 
11. This may refer to the Liverpool School of Tropical Medicine, owing to the context given by Ross and Lever's correspondence.

12. William Lever was an English industrialist and philanthropist best known for manufacturing (with his younger brother) "Sunlight Soap" - a business that relied on palm oil supplied by the British Empire.

13. From the tone of the correspondence and the details of the play, which take place "Christmas 19_" and conclude with many LSTM members getting into Heaven "because it is Christmas Day," the first act may have been sent by Ross to Lever as a private joke.

14. Furthermore, Ross's assertion that "[Africa] is mostly an empire of graveyards, a kingdom over tombstones" allegorically links the colonies with Hade's underworld ("A Recent Medical Expedition").

15. "It seems to me there is far too much red tape in these matters and that an ordinary layman like myself is in much greater danger of damaging the cause he wishes to help [. . .] if he rushes in where angels fear to tread" (Lever 1912). 


\section{Works Cited}

"A Malaria Expedition to West Africa. Interview with Major Ross." The Daily News Weekly 5 Aug. 1899.

"Annals of Tropical Medicine and Parasitology by The Liverpool School of Tropical Medicine." British Medical Journal 2.2595 (1910): 880.

Allman. Poem. 23 Feb. 1919. Ross/146/19/26. The Ross Project. London School of Hygiene and Tropical Medicine, London.

Arata, Stephen. "The Occidental Tourist: Dracula and the Anxiety of Reverse Colonization." Victorian Studies 33.4(1990): 621-45.

Barczewski, Stephanie L. "“"Why must we haunt to them foreign parts?": The Legends of King Arthur and Robin Hood, and British Imperialism." Myth and National Identity in Nineteenth-Century Britain. New York: Oxford UP, 2000.

Beer, Gillian. Darwin's Plots. London: Routledge, 1983.

Brantlinger, Patrick. Rule of Darkness: British Literature and Imperialism, 18301914. Ithaca: Cornell UP, 1988.

Burkert, Walter. Structure and History in Greek Mythology and Ritual. Berkley: U of California P, 1979.

Cobbold, T. Spencer. Entozoa: an Introduction to the Study of Helminthology, with Reference More Particularly to the Internal Parasites of Man. London: Groombridge and Sons, 1864.

“Correspondence." British Medical Journal, January 1903.

Cox, George William. Tales from Greek Mythology London: Longman, Green, Longman and Roberts, 1861.

Dixon, Robert. Writing the Colonial Adventure: Race, Gender and Nation in AngloAustralian Popular Fiction, 1875-1914. Cambridge: Cambridge UP, 1995.

"Empire Leading Article, Imperial Bacteriology." The Financial News 23 Jan. 1913.

"Europeans in the Tropics." British Medical Journal 1.1880 (1897): 93-94.

Faulds, Henry. "The Reward of Research." Cutting from the British Medical Journal, 18 Apr. 1914. Ross/121/01/18. The Ross Project. London School of Hygiene and Tropical Medicine, London.

Giles, G. "The Etiology of "Kala-Azar."” Indian Medical Gazette 33.1 (1898): 1.

Glenny, Lilian. Letter to Ronald Ross. 16 Aug. 1913. Ross/119/25. The Ross Project. London School of Hygiene and Tropical Medicine, London.

Goethe, Johann Wolfgang Von. Faust: Part One. Trans. David Luke. Oxford: Oxford UP, 2008.

Gould, Benjamin Apthorp. Report on the History of the Discovery of Neptune by Benjamin Apthorp Gould Jr. Washington City: Smithonian Institution, 1850.

Hard, Robin. "The Brothers and Sisters of Zeus." The Routledge Handbook of Greek Mythology. London: Routledge, 2004.

"How to Assist Tropical Medical Work" Financial News. 23 Jan. 1913.

"Insect Borne Disease." Cutting from The Daily Graphic. 1907. Ross/113/23/43. The Ross Project. The London School of Hygiene and Tropical Medicine, London.

Letter to Surgeon-Major Owen, medical advisor to the Maharaja of Patiala from the Prime Minister of Patiala State. 2 Feb. 1910. Ross/04/54/03. The Ross Project. The London School of Hygiene and Tropical Medicine, London.

Lever, William. Letter to Ronald Ross. 1912. Ross/121/01. The Ross Project. London School of Hygiene and Tropical Medicine, London.

--- Letter to Ronald Ross. 27 Dec 1911. Ross/113/20/05. The Ross Project. London School of Hygiene and Tropical Medicine, London. 
--- Letter to Ronald Ross. 30 Dec. 1911. Ross/113/20/06. The Ross Project. London

School of Hygiene and Tropical Medicine, London.

"Liverpool." British Medical Journal 1.2192 (1903): 48.

M.W.G. "The Deadly Female. Murder that Mosquito!" The West Australian, Saturday 15 Jan. 1938.

MacCallum. William. "Science and Poetry. Work of Sir Ronald Ross." The West Australian, 13 Feb. 1932.

MacGregor, William “An Address on Some Problems of Tropical Medicine." British Medical Journal. 2.2075 (1900): 977-84.

Manson, Patrick. "Letter 11. 02/004 - $21^{\text {st }}$ June 1895." The Beast in the Mosquito. Ed. W. F. Bynum and Caroline Overy. Amsterdam: Rodopi, 1998.

--- "The Necessity for Special Education in Tropical Medicine." The British Medical Journal 2.1919 (1897): 985-89.

“Martyrs to Science. Medical Men's Toll of Life." Cape Argus 14 Dec 1912.

"Medicine in the Tropics." British Medical Journal 1955 (1898): 909-10.

"Men You Will Hear Of When You Grow Up." The Children's Newspaper 6 Dec. 1919.

Olcott, William Tyler. "Perseus, the Champion." Star Lore: Myths, Legends and Facts. New York: Dover Publications, 2004.

Otis, Laura. Membranes: Metaphors of Invasion in Nineteenth-Century Literature, Science and Politics. Baltimore: John Hopkins UP, 1999.

"Perilous Pets: Diseases Which may be Prevented by Mosquito Nets." Cutting from The Daily Dispatch. n.d. Ross/113/23/42. The Ross Project. The London School of Hygiene and Tropical Medicine, London.

Rosenberg, Charles. "Framing Disease: Illness, Society and History." Framing Disease: Studies in Cultural History. Ed. Charles Rosenberg and Janet Golden. New Brunswick: Rutgers UP, 1992.

Ross, R. and J.G. Thomson. "Experiments on the Treatment of Animals Infected with Trypanosomes, by Means of Atoxyl, Vaccines, Cold, X-Rays and Leucocyte Extract; Enumerative Methods Employed (Preliminary Note)." J. Proceedings of the Royal Society of London. Series B, Containing Papers of a Biological Character (1905-1934) 83.563 (1911): 227-234.

Ross, Ronald. "A British Nobel Prize" 1906. MS. Ross/94. The Ross Project. The London School of Hygiene and Tropical Medicine, London.

--- “A Recent Medical Expedition to West Africa" Liverpool Chamber of Commerce, Liverpool. 27 Nov 1899. Lecture.

--- "Homer, Dante, Shakespeare, and Cervantes" Science Progress, July 1916. Print.

--- "Joseph Everett Dutton, M.B.,Ch. B. Vict, D.P.H." British Medical Journal 1.2314 (1905): 1020-1021.

--- Letter to Sir Alfred Lewis Jones. Dec. 1911. Ross/110/62. The Ross Project. London School of Hygiene and Tropical Medicine, London.

--- Memoirs; with an Account of the Great Malaria Problem and its Solution. London: John Murray, 1923.

Sambon, L. "Remarks on the Possibility of the Acclimatization of Europeans in Tropical Regions.” British Medical Journal 1.1880 (1897): 61-66.

--- "Acclimatization of Europeans in Tropical Lands" The Geographical Journal 12.6 (1898): 589-599.

"Sir Ronald Ross and his Petition." The Abolitionist 6.15 (1914): 126-28.

"Sir Ronald Ross, Famous Scientist Ill." Northern Star, 16 Aug. 1929.

"Sir Ronald Ross." The Brisbane Courier, 20 Sept 1932. 
"Spectoscopic Binary Star." Encyclopaedia Britannica Online. n.d. Web. 10 Jan 2013.

"The Gates of Hades" Dec. 1911. Ross/113/20/07-08. The Ross Project. London School of Hygiene and Tropical Medicine, London.

“The Gates of Paradise" 27 Dec. 1911. Ross/113/20/07-08. The Ross Project. London School of Hygiene and Tropical Medicine, London.

Turner, Frank. The Greek Heritage in Victorian Britain. London: Yale UP, 1981.

Watts, Sheldon. Epidemics and History: Disease, Power and Imperialism. Bath: The Bath Press, 1997.

Webber, Elizabeth and Mike Feinsilber, eds. "Cerberus." Merriam-Webster's Dictionary of Allusions. 1999. Web. 7 Oct 2014.

Yarrow, A. F. Letter to Ronald Ross. 18 Aug 1913. Ross/119/27. The Ross Project. London School of Hygiene and Tropical Medicine, London.

Yumna Siddiqi, Anxieties of Empire and the Fiction of Intrigue. New York: Columbia UP, 2008. 